\title{
ANALISIS KEBUTUHAN PENGEMBANGAN BAHAN AJAR MATA KULIAH KALKULUS PEUBAH BANYAK BERBANTUAN SOFTWARE GEOGEBRA BAGI MAHASISWA PENDIDIKAN MATEMATIKA UNIVERSITAS PASIR PANGARAIAN
}

\section{ANALYSIS OF THE NEEDS OF DEVELOPING MULTIVARIABLE CALCULUS TEACHING MATERIALS ASSISTED BY GEOGEBRA SOFTWARE FOR MATHEMATICS EDUCATION STUDENTS OF PASIR PANGARAIAN UNIVERSITY}

\author{
Annajmi $^{1}$, Ratri Isharyadi ${ }^{2}$ \\ ${ }^{1,2}$ Universitas Pasir Pengaraian, Jln. Tuanku Tambusai Kumu, Rambah Pasir Pengaraian, \\ annajminajmi86@gmail.com, arya_math@ymail.com
}

\begin{abstract}
ABSTRAK
Bahan ajar yang sesuai dengan kebutuhan siswa dapat membantu kelancaran proses perkuliahan berjalan dengan efektif. Kalkulus Peubah banyak merupakan satu mata kuliah wajib yang harus diambil oleh mahasiswa program studi pendidikan matematika. Berkenaan dengan itu bahan ajar menjadi komponen yang penting diperlukan dalam proses perkuliahan. Mata kuliah ini berisi tentang sistem koordinat, fungsi dua peubah yang memerlukan kemampuan berpikir tingkat lanjut. Oleh karena itu diperlukan suatu bahan ajar yang membantu siswa dalam memvisualisasikan materi yang abstrak. Bahan ajar yang ada dan digunakan dalam perkuliahan selama ini merupakan bahan ajar berupa buku teks yang merupakan buku referensi yang beredar dipasaran. Berkenaan dengan itu diperlukan bahan ajar yang disusun oleh dosen dan disesuaikan dengan tingkat kebutuhan mahasiswa yang dilengkapi dengan media visualisasi berbasis teknologi. Tujuan penelitin ini adalah untuk mengentahui kebutuhan bahan ajar yang dikembangkan berbantuan software geogebra. Subjek penelitian ini adalah mahasiswa pendidikan matematika semester lima Universitas Pasir Pengaraian. Data dikumpulkan dengan menggunakan angket analisis kebutuhan dan observasi langsung dalam perkuliahan. Hasil angket menunjukkan diperlukannya bahan ajar berbasis teknologi yang mampu memvisualisasikan materi pembelajaran dimana terdapat $50 \%$ responden diperlukannya media visualisasi dalam pembelajaran, selanjutnya $75 \%$ responden setuju dan $12,5 \%$ sangat setuju digunakannya media berbasis teknologi, dan $66,7 \%$ responden sangat setujua, 33,3 \% setuju digunakannya aplikasi matematika, yaitu software geogebra dalam pembelajaran. Hal ini menunjukkan dibutuhkannya bahan ajar yang berbantuan software geogebra bagi mahasiswa pendidikan matematika universitas pasir pengaraian.
\end{abstract}

Kata kunci: Bahan Ajar, Geogebra, Kalkulus Peubah Banyak

\begin{abstract}
Teaching materials that fit the needs of students can help the smooth running of the lecture process effectively. Calculus of many variables is a compulsory subject that must be taken by students of mathematics education study programs. In connection with that teaching material becomes an important component needed in the lecture process. This course contains the coordinate system, the function of two variables that require advanced thinking skills. Therefore we need a teaching material that helps students in visualizing abstract material. The teaching materials available and used in lectures so far are teaching materials in the form of textbooks which are reference books
\end{abstract}


Analisis Kebutuhan Pengembangan Bahan Ajar Mata Kuliah Kalkulus Peubah Banyak Berbantuan Software Geogebra bagi Mahasiswa Pendidikan Matematika Universitas Pasir Pengaraian

circulating in the market. In this regard, instructional materials are prepared by lecturers and are adjusted to the level of student needs that are equipped with technology-based visualization media. The purpose of this research is to identify the needs of teaching materials developed using geogebra software. The subjects of this study were students of the fifth semester of mathematics education at Pasir Pengaraian University. Data were collected using a needs analysis questionnaire and direct observation in lectures. The results of the questionnaire indicate the need for technology-based teaching materials that are able to visualize learning materials where there are 50\% of respondents need visualization media in learning, then $75 \%$ of respondents agree and $12.5 \%$ strongly agree the use of technology-based media, and $66.7 \%$ of respondents are very much in agreement, $33.3 \%$ agree on the use of mathematical applications, namely geogebra software in learning. This shows the need for teaching materials assisted by geogebra software for university students of mathematics sand education.

Keywords: Teaching Materials, Geogebra, Multivariable Calculus

\section{How to Cite: Annajmi \& Isharyadi, R. (2019). Analisis Kebutuhan Pengembangan Bahan Ajar Mata Kuliah Kalkulus Peubah Banyak Berbantuan Software Geogebra bagi Mahasiswa Pendidikan Matematika Universitas Pasir Pengaraian. Mathline: Jurnal Matematika dan Pendidikan Matematika, Vol.4, No.2, 85-97.}

\section{DOI:}

\section{PENDAHULUAN}

Kalkulus peubah banyak merupakan mata kuliah lanjutan dari kalkulus diferensial dan kalkulus integral. Mata kuliah ini juga menjadi prasyarat untuk mengikuti mata kuliah persamaan differensial dan statistik matematika. Oleh karena mahasiswa harus memiliki penguasaan yang tinggi terhadap mata kuliah ini, selain itu mahasiswa harus memiliki kemampuan berpikir tingkat lanjut dan penguasaan yang komprehensif terhadap mata kuliah ini. Mahasiswa yang mengikuti mata kuliah kalkulus peubah banyak, diharuskan bisa berpikir abstrak dan berpikir kritis dalam melakukan pemecahan masalah. Hal ini dikarenakan materi yang disajikan pada matakuliah ini yaitu fungsi dua peubah atau lebih, sehingga diperlukan daya nalar dan analisis serta imajinasi yang kuat untuk bisa memahami konsep dnegan baik.

Berkaitan dengan itu diperlukan suatu bahan ajar yang sesuai dengan tingkat kebutuhan siswa dalam belajar. Reza (Irawati \& Saifuddin, 2018) menjelaskan bahwa bahan ajar salah satu komponen yang dapat membantu kelancaran belajar siswa maupun mahasiswa. Bahan ajar merupakan segala bentuk bahan yang digunakan untuk membantu pendidik dalam melaksanakan kegiatan belajar mengajar di kelas (Prastowo, 2012). Bahan ajar yang digunakan dalam proses pembelajaran diharapkan bisa membantu mahasiswa untuk memahami materi yang disampaikan, selain itu adanya bahan ajar bisa digunakan mahasiswa untuk belajar secara indiviu ataupun kelompok. 
Menurut (Depdiknas, 2008) bahan ajar adalah segala bentuk bahan yang digunakan untuk membantu pendidik dalam melaksanakan kegiatan belajar mengajar. Bahan yang dimaksud bisa berupa bahan tertulis maupun bahan tidak tertulis. Lebih lanjut disebutkan bahwa bahan ajar berfungsi sebagai:

1. Pedoman bagi Guru yang akan mengarahkan semua aktivitasnya dalam proses pembelajaran, sekaligus merupakan substansi kompetensi yang seharusnya diajarkan kepada siswa.

2. Pedoman bagi siswa yang akan mengarahkan semua aktivitasnya dalam proses pembelajaran, sekaligus merupakan substansi kompetensi yang seharusnya dipelajari/dikuasainya.

3. Alat evaluasi pencapaian/penguasaan hasil pembelajaran

Adanya bahan ajar sebagai sumber belajar mahasiswa dapat membantu mahasiswa dalam meningkatkan kompetensinya dan hasil belajarnya selain mendengarkan penjelasan dari dosen, sehingga perkuliahan akan berjalan dengan efektif. Pembelajaran di perguruan tinggi agar menjadi efektif, antara lain; (1) Ketertarikan mahasiswa terhadap pembelajaran, (2) Apresiasi dan respek terhadap mahasiswa dan cara belajarnya, (3) Ketepatan melakukan asesmen dan umpan balik, (4) Kejelasan tujuan dan minat pada tantangan intelektual, (5) Kemandirian dan (6) Pengendalian dan pengembangan diri secara aktif (Ramden, 2003).

Berdasarkan hasil obervasi ketika perkuliahan berlangsung banyak diantara mahasiswa yang tidak memiliki buku teks tersebut, mereka hanya belajar dari materi yang disampaikan oleh dosen. Hal ini tentunya berpengaruh terhadap hasil belajar yang diperoleh. Hasil analisis terhadap penilaian pada semester sebelumnya dari hasil ujian akhir semester, diperoleh fakta bahwa banyak terdapat mahasiswa yang gagal dalam menyelesaikan soal yang diberikan, persentase mahasiswa yang lulus dengan nilai yang bagus (A atau B) masih sangat rendah, yaitu masih dibawah 50\% dari jumlah siswa. Hasil ini belum optimal dan harusnya hasil tersebut bisa lebih baik. Hal ini terjadi karena materi yang disajikan menuntut mahasiswa mampu berpikir kritis dan kreatif dalam melakukan pemecahan masalah yang berkaitan dengan grafik persamaan dalam ruang dimensi tiga, fungsi dua peubah atau lebih dan grafik fungsi.

Hasil refleksi peneliti sebagai pengampu pada tahun akademik 2017/2018, penyebab belum optimalnya prestasi belajar mahasiswa adalah: a) sebagai pengampu mata kuliah, peneliti telah memberikan kesempatan kepada mahasiswa untuk mendiskusikan kesulitan yang mereka hadapi dalam perkuliahan, namun kesempatan tersebut sedikit 
Analisis Kebutuhan Pengembangan Bahan Ajar Mata Kuliah Kalkulus Peubah Banyak Berbantuan Software Geogebra bagi Mahasiswa Pendidikan Matematika Universitas Pasir Pengaraian

mahasiswa yang memanfaatkannya; b) perkuliahan belum menggunakan buku ajar buatan sendiri dan mahasiswa hanya mengandalkan satu buku teks. Selain itu hanya sebagian kecil mahasiswa yang memiliki buku teks, sebagian besar lainnya hanya belajar dari materi yang disampaikan dosen baik secara langsung maupun melalui slide power point. Mahasiswa mengalami kesulitan memahami materi perkuliahan. Sulitnya memahami materi Kalkulus Peubah Banyak karena kurang didukung oleh sumber belajar dan media yang digunakan. Berkaitan dengan itu perlu dikembangkan bahan ajar yang dikombinasikan dengan penggunaan media yang berbasis teknologi. Penggunaan teknologi multimedia dapat menciptakan suatu media pembelajaran dengan kombinasi teks, gambar, seni grafik, animasi, suara, dan video. Aneka media tersebut ketika digabungkan menjadi satu kesatuan kerja akan menghasilkan suatu informasi dengan nilai komunikasi yang sangat tinggi, ehingga memberikan rangsangan dan stimulus yang kuat bagi mahasiswa untuk terus belajar (Oetomo \& Dharma, 2002).

Pemanfaatan multimedia dalam pembelajaran terdapat beberapa keuntungan seperti yang dikemukan oleh Roblyer (2000) diantaranya, yaitu:

1. Lahirnya motivasi yang dapat meningkatkan perhatian siswa, melibatkan siswa dalam menghasilkan pekerjaan dan meningkatkan kontrol belajar.

2. Kapabilitas pengajaran (instruksional) yang unik yang dapat meghubungkan siswa pada sumber informasi, menolong siswa memvisualisasikan masalah dan persoalan, pelacakan perkembangan belajar, menghubungkan siswa pada learning tools.

3. Dukungan terhadap pendekatan pengajaran baru yaitu cooperatif, share intelegence, problem solving, dan kecakapan intelektual tingkat tinggi.

4. Peningkatan produktivitas pengajar di mana pengajar memiliki waktu luang untuk membantu siswa/mahasiswa selama pembelajaran (sebagai fasilitator), menyediakan informasi yang lebih akurat dan cepat, memberi kesempatan pengajar untuk memproduksi bahan pembelajaran menjadi lebih menarik dan studentfriendly secara cepat.

5. Membantu melatih kecakapan yang dibutuhkan dalam era teknologi informasi antara lain untuk melek teknologi, informasi dan visual.

Teknologi yang bisa dimanfaatkan seperti aplikasi-aplikasi yang bisa digunakan dalam pembelajaran matematika seperti software geogebra. Software ini dapat membantu mahasiswa dalam memvisualisasikan bentuk kurva ataupun persamaan aljabar dalam bidang kartesius dimensi dua dan tiga, grafik fungsi pada ruang dimensi tiga. Software geogebra dirancang oleh Markus Hohenwater tahun 2001/2002. Program ini merupakan 
open source, sehingga dapat diakses secara gratis. Software ini terdiri dari gabungan dua kajian matematika yang geometri dan aljabar, sehingga dapat dengan mudah menampilkan bentuk dari suaru kurva dan persamaan aljabar. Geogebra merupakan kependekan dari geometry (geometri) dan algebra (aljabar), tetapi program ini tidak hanya mendukung untuk kedua topik tersebut, tapi juga mendukung banyak topik matematika di luar keduanya. Software Geogebra dapat digunakan untuk mengkonstruksi dengan memanfaatkan titik-titik, vektor-vektor,segmen-segmen, daris-garis, bagian konik dan fungsi yang dapat diubah secara dinamik. Geogebra merupakan software serbaguna untuk pembelajaran matematika di sekolah menengah. Geogebra dapat dimanfaatkan untuk media demontrasi dan visualisasi, alat bantu kontruksi, alat bantu penemuan konsep matematika, dan untuk menyiapkan bahan-bahan pengajaran (Hohenwarter, 2004)

Pemanfaatan Geogebra sebagai media pembelajaran dapat digunakan untuk menjelaskan konsep matematika atau dapat juga digunakan untuk eksplorasi, baik untuk ditayangkan oleh guru/dosen di depan kelas atau siswa/mahasiswa bereksplorasi menggunakan komputer sendiri. Beberapa keuntungan dari penggunaan Geogebra dalam pembelajaran geometri, diantaranya: (1) Lukisan-lukisan geometri yang biasanya dihasilkan dengan cepat dan teliti dibandingkan dengan menggunakan pensil, penggaris, atau jangka, (2) Adanya fasilitas animasi dan gerakan-gerakan manipulasi (dragging) pada program Geogebra dapat memberikan pengalaman visual yang lebih jelas kepada siswa dalam memahami konsep geometri, (3) Dapat dimanfaatkan sebagai balikan/evaluasi untuk memastikan lukisan yang telah dibuat benar, (4) Mempermudah guru/siswa untuk menyelidiki atau menunjukkan sifat-sifat yang berlaku pada suatu objek geometri. (Mahmudi, 2010)

Bahan ajar berbantuan software geogebra yang dikembangkan akan dapat membantu mahasiswa dengan mudah meningkatkan kompetensinya dalam mempelajari materi pada kalkulus peubah banyak. Penelitian yang dilakukan oleh Zulnaidi \& Zakaria (2012), menunjukkan bahwa penggunaan software geogebra dapat meningkatkan kemampuan matematika siswa pada materi fungsi dan fungsi kuadrat Sehubungan dengan itu memperhatikan kebutuhan berdasarkan studi literature yang telah dilakukan, perlu dilakukan pula analisis kebutuhan berdasarkan pengguna bahanajar, yaitu mahasiswa. Oleh karena itu, tujuan penelitian ini adalah untuk melihat kebutuhan bahan ajar kalkulus peubah banyak berbantuan software geogebra bagi mahasiswa Pendidikan Matematika Universitas Pasir Pengaraian. 


\section{METODE PENELITIAN}

Penelitian ini merupakan penelitian deskriptif kualititaif dengan metode survey yang dilaksanakan pada bulan Mei-Juli 2019 di program studi pendidikan matematika Universitas Pasir Pengaraian Riau. Sampel penelitian adalah seluruh mahasiswa semester lima program studi pendidikan matematika yang telah pernah mengambil mata kuliah kalkulus peubah banyak yang berjumlah 24 mahasiswa. Teknik pengumpulan data dengan observasi dan angket. Instrumen pengumpulan data dengan menggunakan lembar observasi dan angket. Lembar observasi digunakan untuk memperoleh data tentang kegiatan pembelajaran mata kuliah kalkulus peubah banyak. Angket digunakan untuk memperoleh data tentang sumber belajar yang selama ini digunakan oleh mahasiswa, kebutuhan bahan ajar yang diinginkan oleh mahasiwa. Angket analisis kebutuhan berisi 10 pernyataan dengan empat pilihan jawabannya yaitu Sangat Tidak Setuju (STS), Tidak Setuju (TS), Setuju (S), dan Sangat Setuju (SS). Data hasil angket dianalisis secara deskriptif kualitatif, yang digambarkan dalam sebuah grafik, selanjutnya dianalisis setiap item pernyataan yang ada pada angket.

\section{HASIL DAN PEMBAHASAN}

Penelitian ini bermaksud untuk menganalisis kebutuhan pengembangan bahan ajar berbantuan software geogebra untuk menunjang proses pembelajaran mata kuliah kalkulus peubah banyak bagi mahasiswa pendidikan matematika Universitas Pasir Pengaraian. Data angket analisis kebutuhan bahan ajar yang telah diperoleh, selanjutnya dianalisis secara deskriptif. Adapun data hasil angket diuraikan berikut ini.

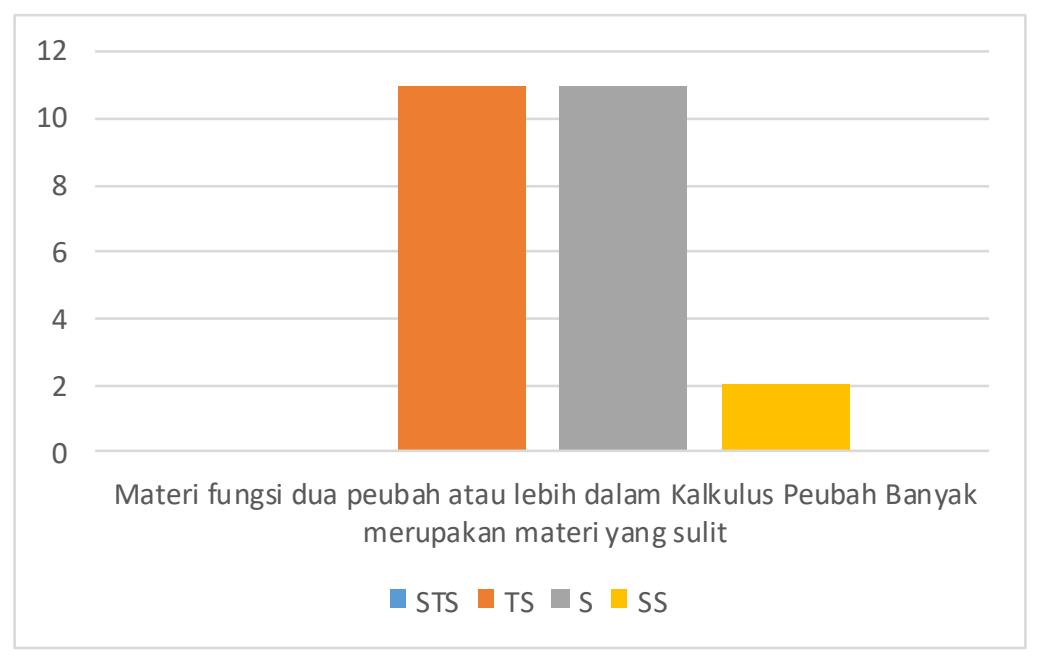

Gambar 1. Respon Mahasiswa terhadap Pernyataan Pertama 
Gambar 1 menunjukkan respon mahasiswa sebagai responden terhadap pernyataan pertama, dimana terdapat angka yang sama antara pernyataan tidak setuju (TS) dan Setuju (S) yang menganggap materi pada mata kuliah kalkulus peubah banyak sebagai materi yang sulit yaitu terdapat $45,5 \%$ dan yang sangat setuju terdapat $8,3 \%$ yang mengatakan sulit dari 24 orang mahasiswa sebagai responden.

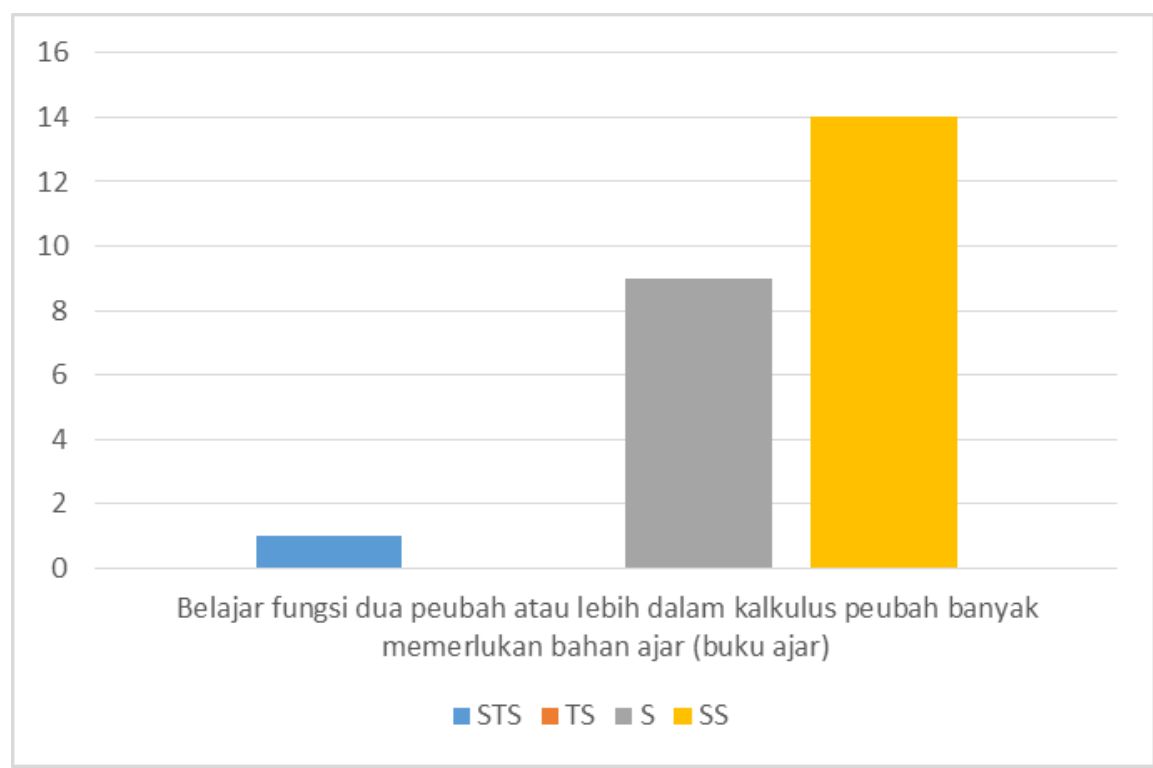

Gambar 2. Respon Mahasiswa terhadap Pernyataan Kedua

Pernyataan kedua respon mahasiswa terhadap perlunya bahan ajar dalam perkuliahan, dimana terdapat 58,3\% sangat setuju dan 37,5\% menyatakan setuju. Namun terdapat $4,17 \%$ yang sangat tidak setuju. Hal ini menunjukkan bahwasanya mahasiswa memerlukan bahan ajar yang disusun sendiri oleh dosen, sehingga mampu membantu mahasiswa untuk memahami materi perkuliahan baik secara individu maupun kelompok. Hal ini dikarenakan selama ini dalam perkuliahan lebih banyak mahasiswa yang tidak memiliki bahan ajar, mahasiswa hanya belajar dari materi yang disampaikan oleh dosen. 

Berbantuan Software Geogebra bagi Mahasiswa Pendidikan Matematika Universitas Pasir Pengaraian

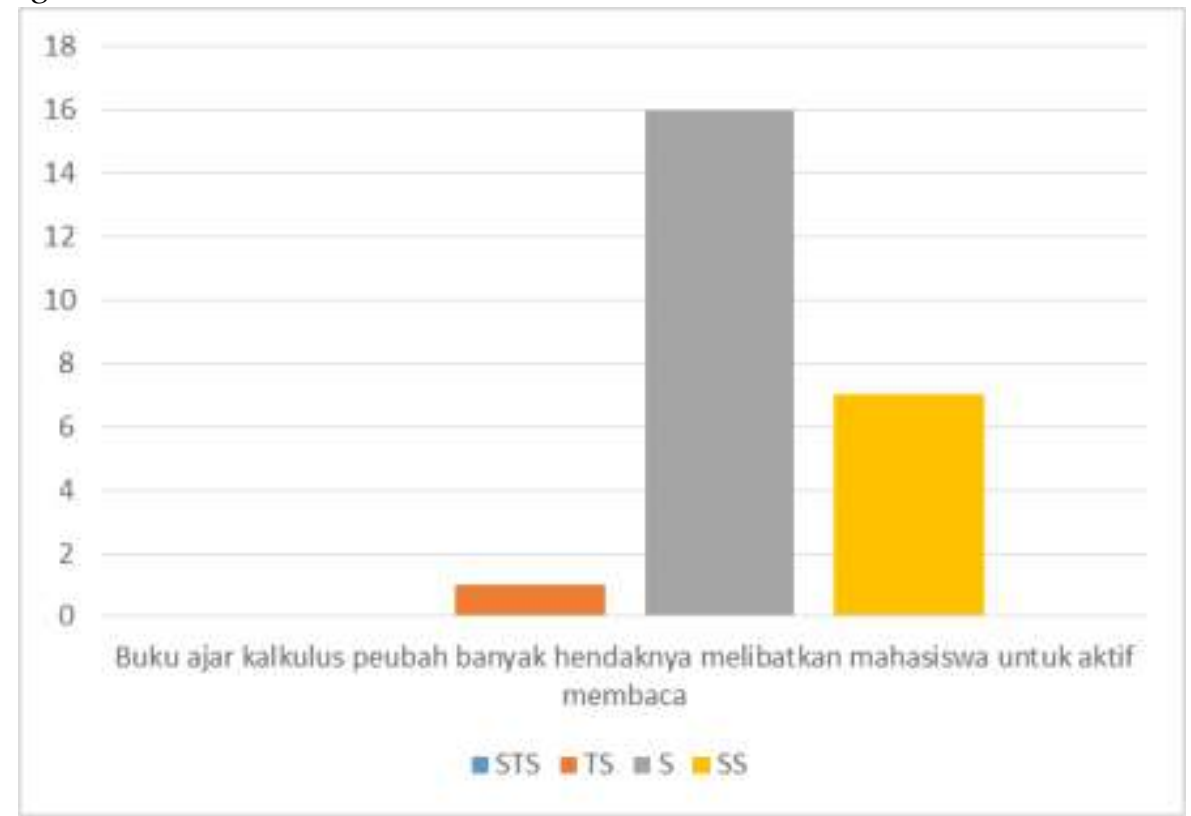

Gambar 3. Respon Mahasiswa terhadap Pernyataan Ketiga

Respon mahasiswa terhadap pernyataan ini terdapat 66,7\% yang setuju, 29,2\% yang sangat setuju 29,2\%, untuk dikembangkan suatu bahan ajar yang bisa melibatkan mahasiswa untuk aktif membaca, namun terdapat 4,2\% yang tidak setuju. Bahan ajar yang dikembangkan diharapkan juga bisa melibatkan mahasiswa untuk bisa aktif membaca, tidak hanya mendengar penjelasan yang disampaikan oleh dosen, namun mahasiswa bisa dilibatkan untuk terlebih dahulu membaca untuk belajar secara mandiri.

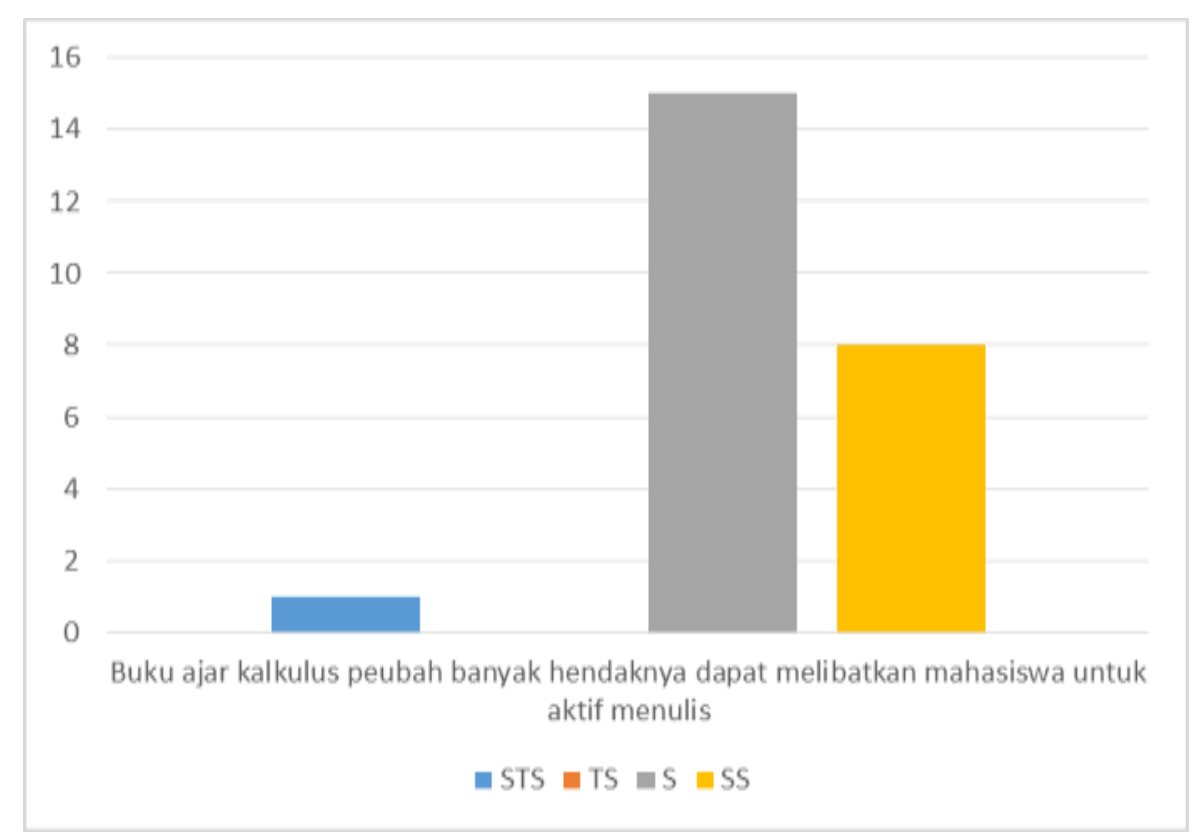

Gambar 4. Responden Mahasiswa terhadap Pernyataan Keempat

Gambar 4 merupakan respon mahasiswa terhadap pernyataan perlunya bahan ajar yang bisa melibatkan mahasiswa untuk aktif menulis terdapat $62,5 \%$ setuju dan sangat setuju 
sebesar 33,3\%, namun terdapat 4,2\% yang sangat tidak setuju. Bahan ajar yang dikembangkan selain adanya penjelasan materi, juga perlu dilengkapi latihan-latihan ataupun tugas yang mengharuskan siswa untuk menulis, dalam hal ini mahasiswa akan terlatih dalam menggambar grafik fungsi, selain itu juga bisa melibatkan mahasiswa untuk belajar mandiri.

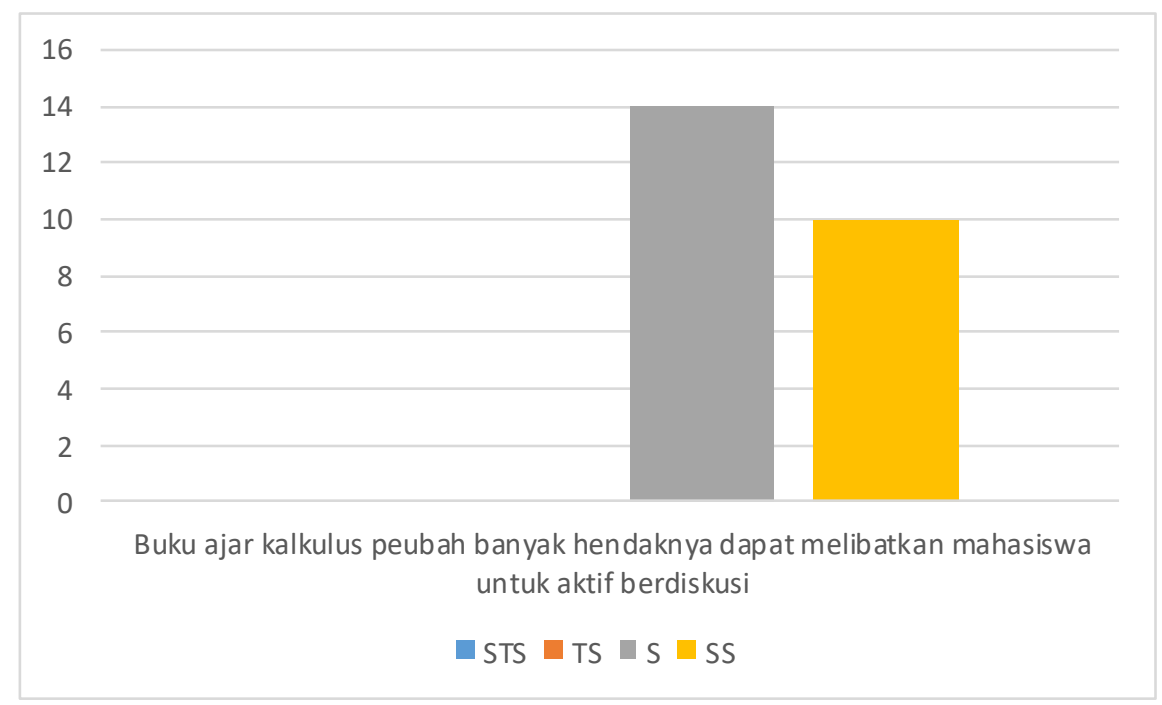

Gambar 5. Respon Mahasiswa terhadap Pernyataan Kelima

Respon mahasiswa terhadap pernyataan bahwa bahan ajar sebaik juga bisa melibatkan siswa untuk aktif berdiskusi, dimana terdapat responden yang setuju 58,3\% dan responden yang sangat setuju 41,7\%. Bahan ajar yang dikembangkan juga perlu dilengkapi dengan bahan diskusi yang bisa melatih mahasiswa untuk bekerja sama, sehingga aktif berbagi ide/gagasannya dalam memahami materi perkuliahan. Hal ini diharapkan terciptanya komunitas belajar, mahasiswa tidak hanya menerima materi dari yang disampaikan dosen. 

Berbantuan Software Geogebra bagi Mahasiswa Pendidikan Matematika Universitas Pasir Pengaraian

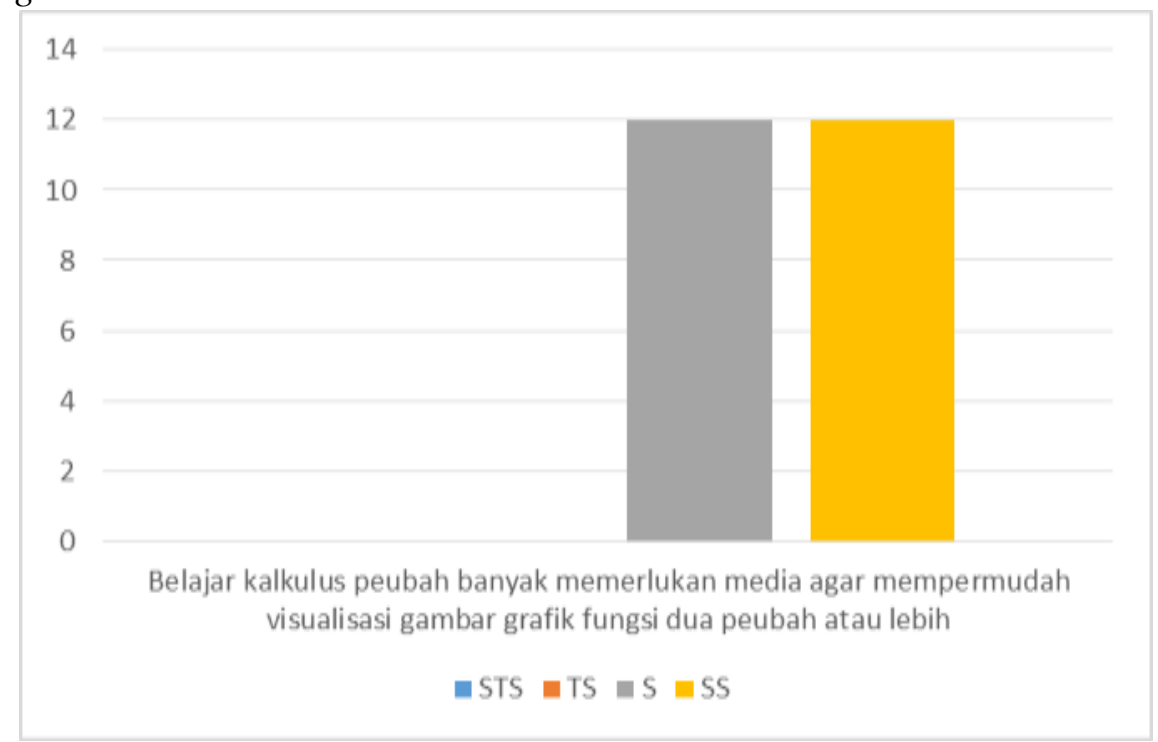

Gambar 6. Respon Mahasiswa terhadap Pernyataan Keenam

Gambar 6 menunjukkan respon mahasiswa terhadap perlunya media dalam pembelajaran untuk membantu dalam memvisualisasikan grafik fungsi dua peubah atau lebih. Responden Setuju dan Sangat Setuju terdapat persentase yang sama yaitu 50\%. Hal ini menunjukkan bahwa mahasiswa memerlukan suatu bahan ajar yang juga dilengkapi dengan suatu media yang bisa digunakan untuk memvisualisasikan materi yang dipelajari.

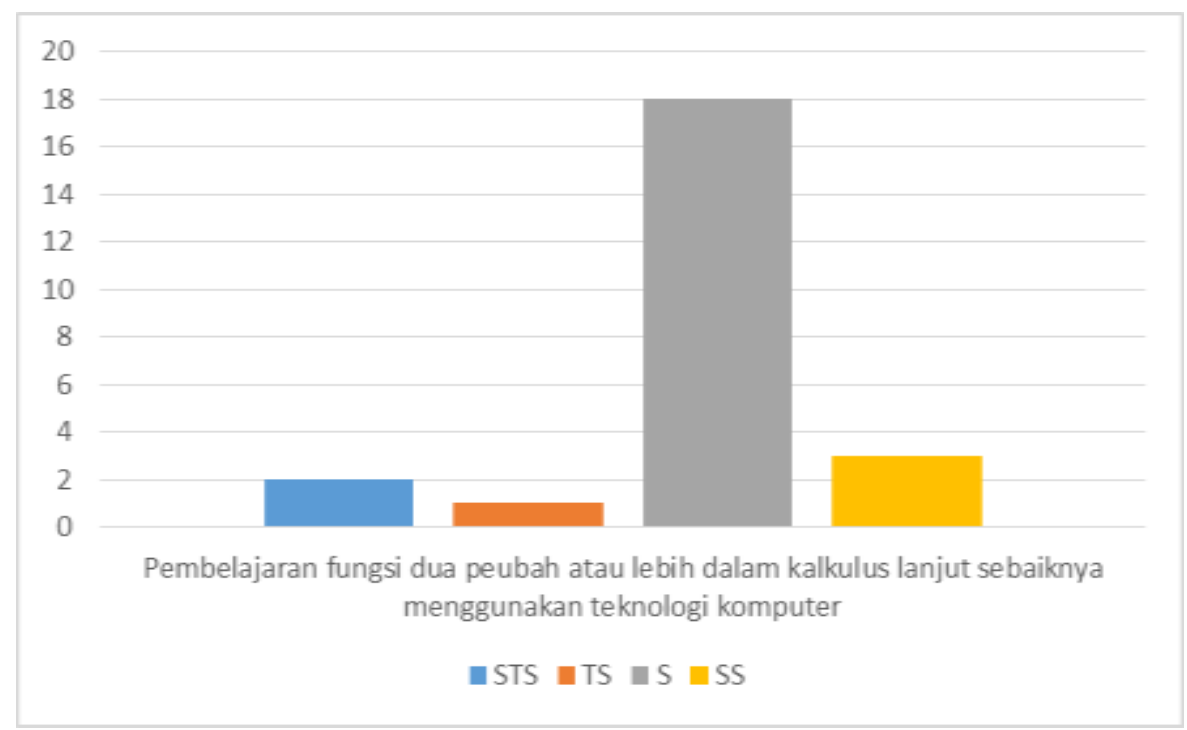

Gambar 7. Respon Mahasiswa terhadap Pernyataan Ketujuh

Gambar 7 merupakan respon mahasiswa terhadap pernyataan diperlukannya media berbasis teknologi komputer dalam pembelajaran terdapat yang setuju sebanyak $75 \%$, dan yang sangat setuju $12,5 \%$ namun terdapat yang tidak setuju $4,17 \%$ dan sangat tidak setuju $8,3 \%$. Hal ini berarti respon mahasiswa lebih besar menginginkan adanya dalam mata kuliah kalkulus peubah banyak menggunakan media berbasis teknologi kumputer. Bahan 
ajar yang dikembangkan perlu digunakan teknologi komputer sebagai media dalam memvisualisasikan materi pembelajaran yang lebih banyak bersifat abstrak.

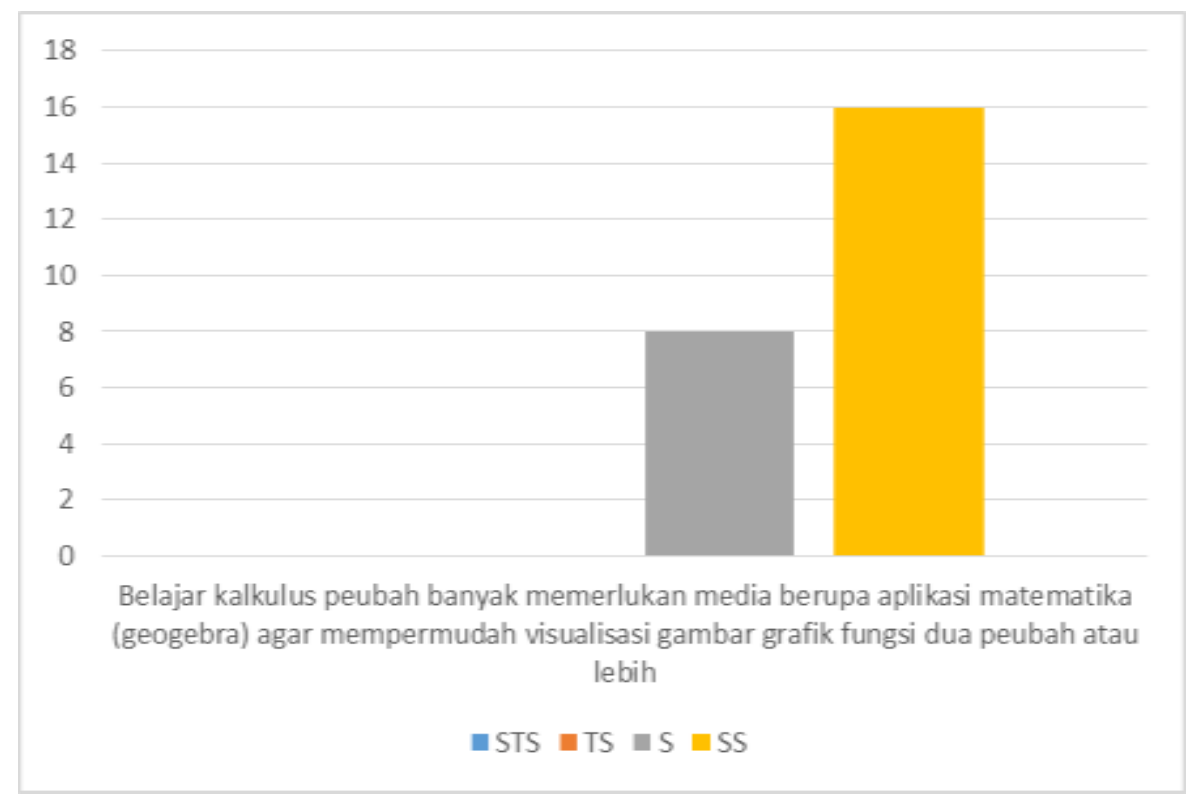

Gambar 8. Respon Mahasiswa terhadap Pernyataan Kedelapan

Gambar 8 menunjukkan respon mahasiswa terhadap keperluan suatu aplikasi matematika seperti software geogebra dalam pembelajaran, dimana terdapat $66,7 \%$ mahasiswa sangat setuju, dan terdapat $33,3 \%$ setuju. Hal ini berarti perlu dikembangkan bahan ajar yang menggunakan media berupa aplikasi matematika yaitu software geogebra dalam pembelajaran. Bahan ajar yang disusun dilengkapi dengan pemanfaatan software geogebra beserta langkah-langkahnya akan bisa membantu mahasiswa untuk memvisualisasikan materi-materi perkuliahan yang lebih banyak bersifat abstrak. Mahasiswa terlibat aktif dalam pembelajaran, bahan ajar bisa digunakan mahasiswa untuk belajar mandiri baik individu maupun kelompok. 

Berbantuan Software Geogebra bagi Mahasiswa Pendidikan Matematika Universitas Pasir Pengaraian

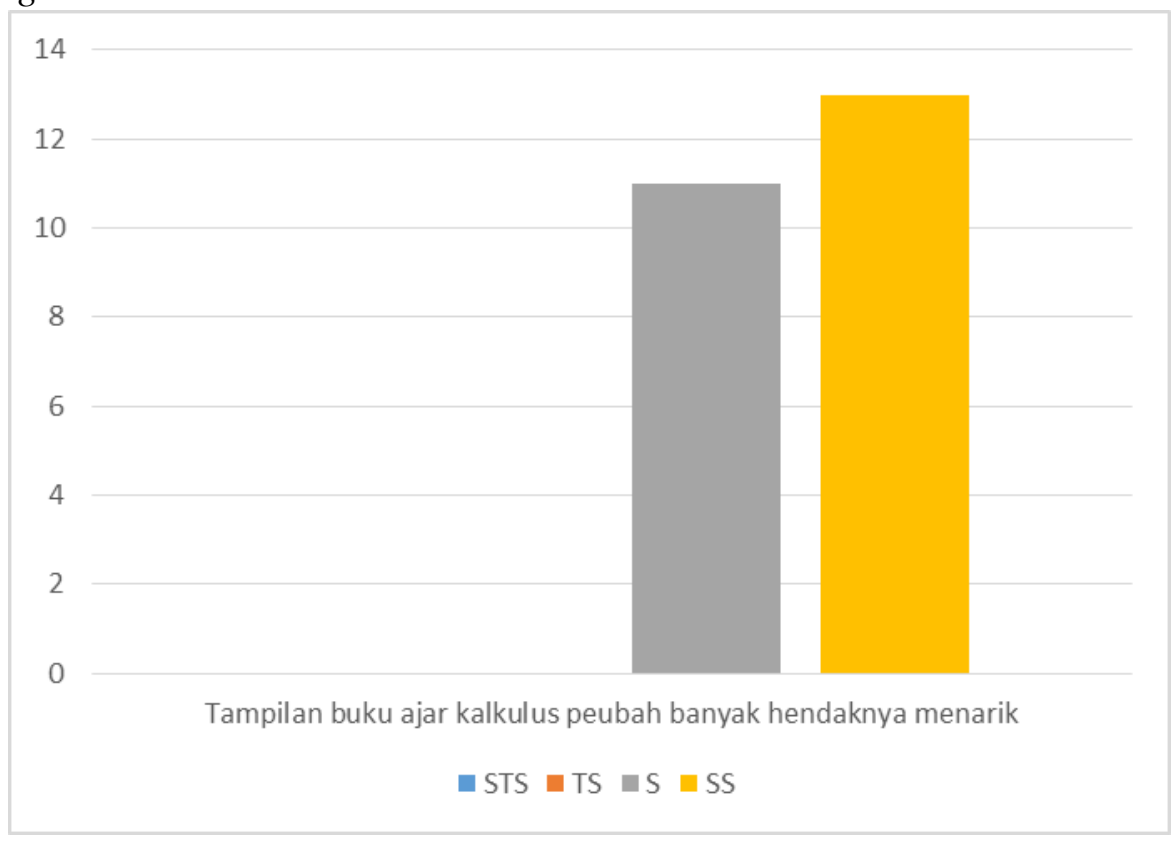

Gambar 9. Respon Mahasiswa Pernyataan Kesembilan

Gambar 9 memberikan gambarkan terhadap pernyataan kesembilan, bahwa bahan ajar yang dikembakan haruslah menarik, dimana terdapat responden yang setuju 45,8\% dan yang sangat setuju 54,2\%. Bahan ajar yang dikembangkan perlu dilengkapi dengan gambar dan kombinasi warna yang menarik, sehingga bisa memberikan motivasi kepada mahasiswa untuk membaca dan mengerjakan latihan-latihan yang diberikan dalam bahan ajar tersebut.

\section{KESIMPULAN}

Berdasarkan hasil penyebaran angket analisis kebutuhan terhadap pengembangan bahan ajar berbantuan geogebra dimana, dibutuhkankannya oleh mahasiswa suatu bahan ajar yang mampu memvisualisasikan objek matematika yang bersifat abstrak dalam mata kuliah kalkulus peubah banyak. Responden memilih setuju dan sangat setuju 50\% diperlukannya media visualisasi dalam pembelajaran, sangat setuju 12,5\% dan setuju $75 \%$ digunakannya media berbasis teknologi, dan $66,7 \%$ sangat setuju dan $33,3 \%$ setuju untuk dikembangkannya bahan ajar yang dilengkapi dengan aplikasinya menggunakannya software geogebra. Bahan ajar yang dikembangkan tersebut dapat dimanfaatkan secara individu maupun kelompok. Hal ini dikarenakan bahan ajar berbantuan geogebra merupakan konsep pembelajaran yang menekankan kemandirian kepada mahasiswa dalam memahami materi perkuliahan. Dengan demikian akan mampu mewujudkan pemahaman mahasiswa dalam memahami materi perkuliahan dengan baik. 


\section{UCAPAN TERIMAKASIH}

Ucapan terimakasih disampaikan kepada Universitas Pasir Pengaraian khususnya Lembaga Penelitian dan Pengabdian Masyarakat dan Kementerian Riset Teknologi dan Pendidikan Tinggi melalui Dirjen Riset Penelitian dan Pengabdian yang telah membantu dalam pembiayaian pelaksanaan penelitian ini pada skema Penelitian Dosen Pemula (PDP)

Pendanaan Tahun 2019.

\section{DAFTAR PUSTAKA}

Depdiknas, (2008). Panduan Pengembangan Bahan Ajar. Jakarta

Hohenwarter, M. D. (2004). Combination of Dynamic Geometry, Algebra and Calculus in the Software System Geogebra: www.geogebra.org/publication/pecs_2004.pdf

Irawati, H \& Saifuffin, M. (2018). Analisis Kebutuhan Pengembangan Bahan Ajar Mata Kuliah Pengantar Profesi Guru Biologi di Pendidikan Biologi Universitas Ahmad Dahlan Yogyakarta. BIO-PEDAGOGI Jurnal Pembelajaran Biologi, 48 - 51.

Mahmudi, A. (2010). Membelajarkan Geometri dengan Program Geogebra. Seminar Nasional Matematika dan Pendidikan Matematika. Yogyakarta: FMIPA UNY.

Oetomo dan Dharma, B. (2002). e-Education Konsep, Teknologi dan Aplikasi Internet Pendidikan. Yogyakarta: Andi.

Prastowo, A. (2012). Panduan Kreatif Membuat Bahan Ajar Inovatif. Yogyakarta: Diva Press.

Ramden, P. (2003). Learning to Teach in Higher Education. London: RoutledgeFalmer.

Roblyer, M.D, Castine, W.H dan King, F.J. (2000) Assesing the impact of computer based instruction: A revie of recent research. New York: Haworth Press

Zulnaidi, H., \& Zakaria, E. (2012). The effect of using GeoGebra on conceptual and procedural knowledge of high school mathematics students. Asian Social Science, $8(11), 102-106$. 